\title{
A challenging diagnosis: Recurrent nevus or melanoma
}

\section{Gonca Elçin, ๑ Sema Koç Yıldırım*, ๑ Özay Gököz**, ๑ Sibel Doğan Günaydın, ๑ Önder Bozdoğan***, ๑ Harald Kittler****}

Hacettepe University Faculty of Medicine, Department of Dermatology and Venereology, Ankara, Turkey

*Afyonkarahisar State Hospital, Clinic of Dermatology, Afyonkarahisar, Turkey

**Hacettepe University Faculty of Medicine, Department of Pathology, Ankara, Turkey

***Ankara Numune Training and Research Hospital, Clinic of Pathology, Ankara, Turkey

****Medical University of Vienna, Department of Dermatology, Vienna, Austria

\begin{abstract} on a scar region after a while later compound nevus excision.

Keywords: Melanoma, recurrent nevus, recurrent melanocytic lesion

\section{Öz} skar yerinden gelişmiş bir melanom olgusu sunulmuştur.

Anahtar Kelimeler: Melanom, rekürren nevüs, rekürren melanositik lezyon

\section{Introduction}

Pigmentation recurring on the site of a removed melanocytic lesion is often a diagnostic challenge due to its clinical and pathologic resemblance to melanoma. Herein, we present a case with post-excisional repigmentation on the scar site of a totally excised compound nevus that was diagnosed as melanoma after the pathologic examination of the total excision of the post-excisional repigmentation.
\end{abstract}

Recurrent pigmentations on scars after melanocytic tumor excision can be confusing due to its similarities to melanoma. Meanwhile, these conditions which can be mixed with malignant conditions also cause difficulties in diagnosis. Herein, we present a melanoma case developed

Melanositik tümör eksizyonu sonrası skar üzerinden gelişen pigmentasyonlar, melanoma benzerlikleri nedeniyle kafa karıştııııı olabilmektedir. Malignite ile karışabilen bu durumlar, tanıda güçlüklere de neden olmaktadır. Bu çalışmada, birleşik nevüs eksizyonundan kısa bir süre sonra

\section{Case Report}

A 26-year-old female was admitted with a diagnosis of melanoma. History revealed a total excision for a growing nevus on the forehead 3 years ago with a pathologic diagnosis of compound nevus with intact surgical margins. The patient clearly remembered that there was recurring pigmentation on the scar site at the time of suture removal 10 days after the total excision of the nevus, however no additional excision was planned depending on the pathology report. Although the post-excisional repigmentation progressively increased and extended beyond the borders of the scar in the following months, she was reluctant to re-visit her doctor due to the fact that the pathology report was benign. However, 3 years after the first total excision, the recurrent lesion was totally excised due to its prominent bizarre shape, which was very eye-catching to anybody (Figure 1).

Address for Correspondence/Yazışma Adresi: Sema Koç Yıldırım MD, Afyonkarahisar State Hospital, Clinic of Dermatology, Afyonkarahisar, Turkey Phone: +90 5367371594 E-mail: semakocyildirim@gmail.com Received/Geliş Tarihi: 05.08.2019 Accepted/Kabul Tarihi: 11.11.2019 ORCID: orcid.org/0000-0002-0633-1770

CCopyright 2020 by Turkish Society of Dermatology and Venereology

Turkderm - Turkish Archives of Dermatology and Venereology published by Galenos Yayınevi. 
This time the pathologic examination revealed a superficial spreading melanoma with a tumour thickness of greater than $0.8 \mathrm{~mm}$ and less than $1 \mathrm{~mm}$ without ulceration. Dermatologic examination at the time of referral to our hospital revealed only a $2.0 \times 0.6 \mathrm{~cm}$ linear scar on the left forehead. Paraffin embedded tissue blocks from the first excision

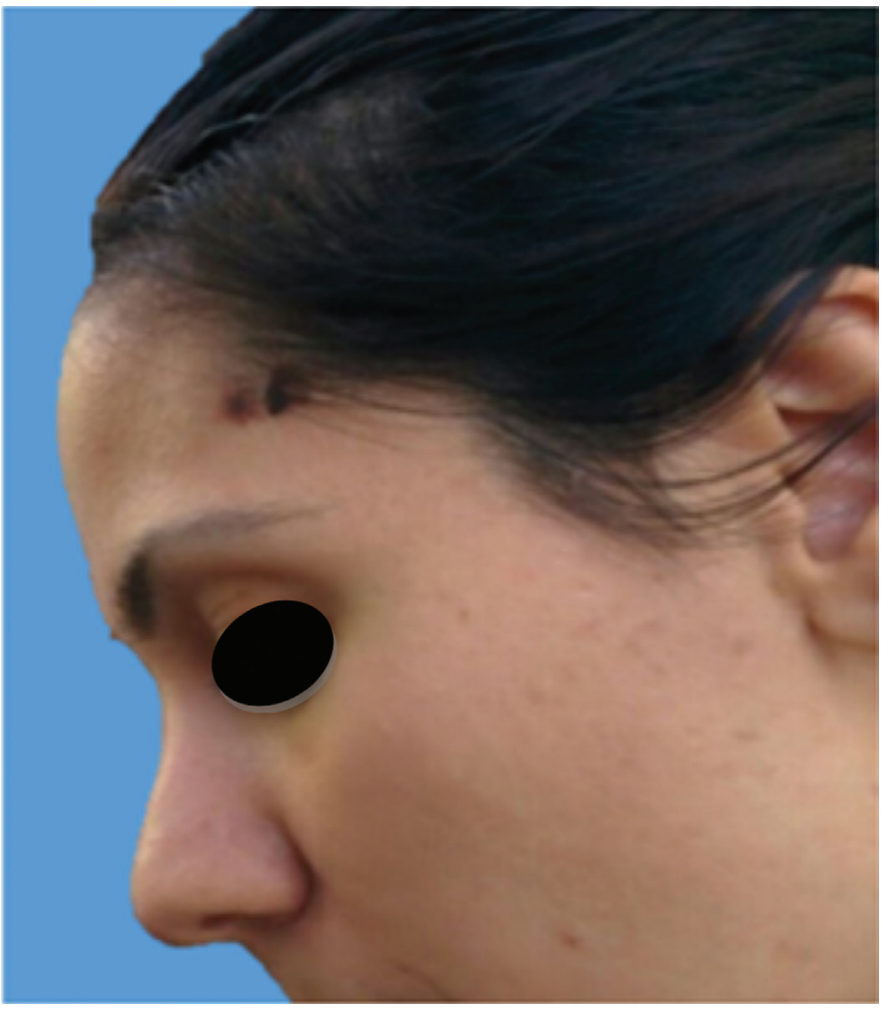

Figure 1. Reappearance of a bizarre shaped, brown pigmented macule on and beyond the scar at the left side of the forehead

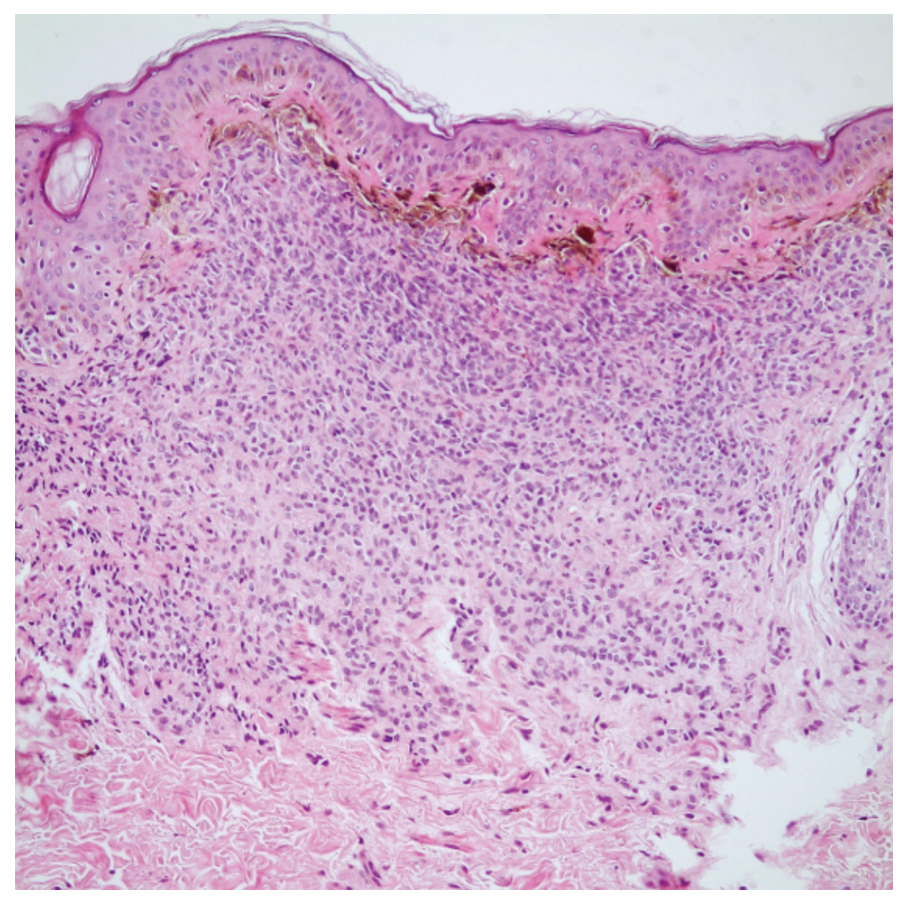

Figure 2. The previously excised lesion was a melanocytic lesion with a minor junctional component. (hematoxylin and eosin, $\mathrm{x} 100$ ) were sectioned totally. Pathology slides and new series of sections from paraffin embedded tissue blocks that belong to the first total excision were interpreted as compound nevus (Figures 2, 3). In pathological examination of the recurrent lesion there were atypical pleomorphic melanocytes with nucleolar prominence proliferating in a somewhat haphazard fashion in the dermis distant from the scar tissue and was diagnosed as superficial spreading melanoma again (Figure 4).

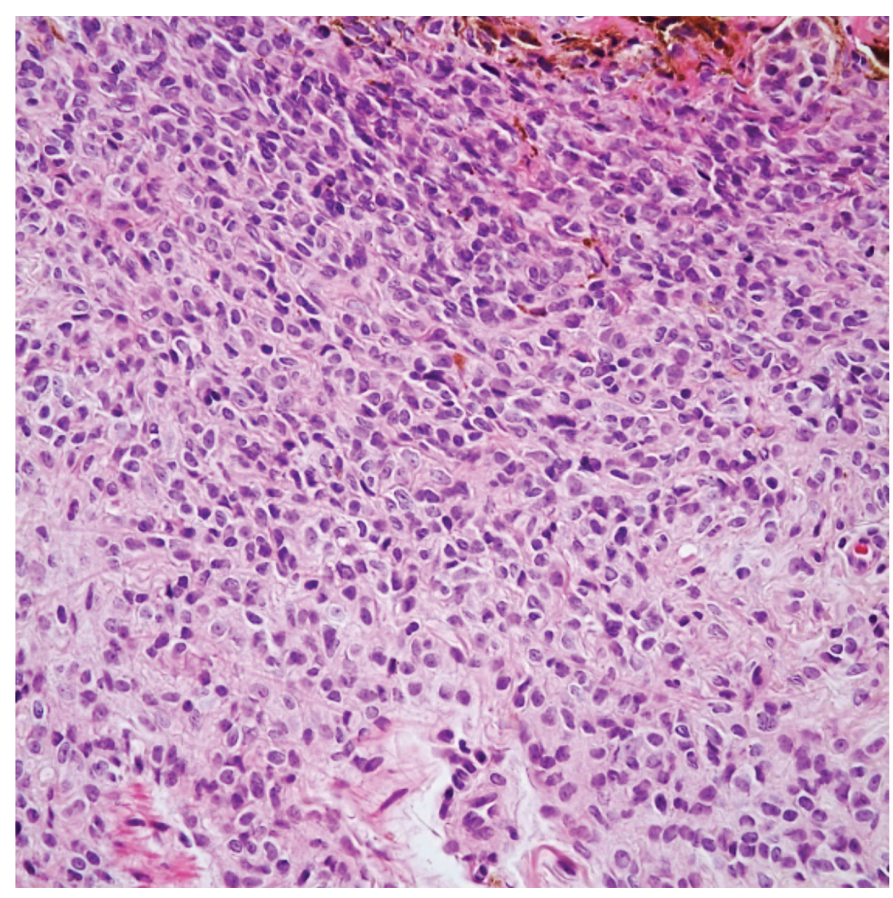

Figure 3. The crowded melanocytes were cytologically bland without any features suggesting malignancy (hematoxylin and eosin, x200)

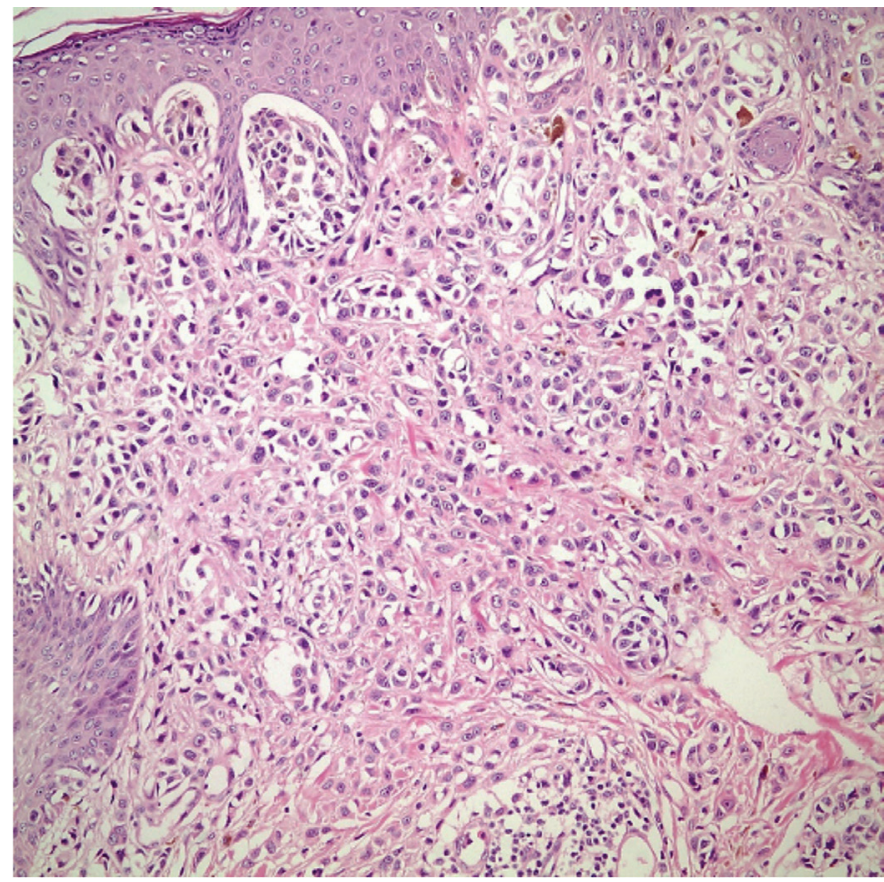

Figure 4. There were atypical pleomorphic melanocytes with nucleolar prominence in the dermis distant from the scar tissue (hematoxylin and eosin, $x 200$ ) 
Although the first and the second pathologists were completely in agreement with each other, we decided to consult the specimens to a third dermatopathologist because it was very unlikely that a compound nevus could recur as melanoma. The result of the third pathologic consultation was again melanoma for the recurrent lesion and compound nevus for the first total excision.

Also, fluorescence in situ hybridization (FISH) was performed both for the primary and recurrent lesions. FISH analysis of the primary lesion revealed normal CCND1 pattern and no CDKN2A gene lost, which were reported as negative for melanoma.

In contrast, FISH analysis of the recurrent lesion displayed RREB and CCND1 genes copy gain and MYB gene lost which were over the cutoff values and accepted as positive for melanoma. With these clinical and pathologic data, the patient was diagnosed as stage IB melanoma and underwent a second re-excision with $1 \mathrm{~cm}$ surgical margins. Although indicated for stage IB melanoma patients, sentinel lymph node biopsy was discussed with the patient but not performed. The patient had regular examinations with 6-month intervals since then and has no further complaints or complications up to now during the 2-year follow-up period. Informed consent was obtained.

\section{Discussion}

Pigmentation on the site of a removed melanocytic lesion is unpleasant for patients and challenging for clinicians. Recurrence of melanocytic lesions usually occurs after inappropriate excision methods such as shave biopsy or electrodesiccation'. In a study that evaluated postexcisional melanocytic regrowth, it was found that the primary lesions were incompletely excised in $40 \%$ of the cases ${ }^{2}$. In another study it was reported that the method of excision was shave excision for all of those recurrent nevi cases ${ }^{3}$. Unlike these examples, in our case the method of excision was standard elliptical excision and the pathology report declared that the surgical margins were intact. Since the lesion has recurred, it is likely that the excision was incomplete, although this was not evident in the sections assessed.

Pathologic features of recurrent nevus and melanoma may be very similar ${ }^{47}$. Kornberg and Ackerman ${ }^{4}$ suggested some clues to distinguish recurrent nevus from melanoma. Kelly et al. ${ }^{2}$ paid attention to the progressive growth pattern and claimed that progressive growth pattern might point out malignant lesions. The most high-lightened feature in common is that the post excisional melanocytic proliferation stays within the scar in recurrent nevus, while this proliferation extends beyond the scar in melanoma $2,5,8,9$. Ancillary diagnostic tools other than standard pathologic examination such as immunohistochemistry, dermoscopy and confocal microscopy have been utilized in order to distinguish recurrent nevus from melanoma ${ }^{5,8,9}$. The distinctive features of these diagnostic tools described in the literature are summarized in Table 1. FISH analysis has also been utilized for the differential diagnosis of recurrent nevus versus melanoma despite some limitations ${ }^{10}$.

In our case, the melanocytic proliferation extending beyond the scar was one of the suggestive features of recurrent melanoma. Confusingly, pathologic examination by 2 different pathologists and a third very competent dermatopathologist revealed that the first lesion was a compound nevus. We saw with interest that there have been similar unexpected examples reported in the literature before. In a 9-case series of recurrent melanocytic lesions, the re-examination of the initial lesions, which were reported as benign on initial histologic examination, revealed 6 cases of previously missed melanomas. The vast majority represented small foci of in situ superficially spreading melanomas ${ }^{2}$.

We know that the development of melanoma on the scar of a benign melanocytic nevus is very unlikely. The most logical explanation for our case is that the pathologic slides of the first excision could not have displayed the foci of melanoma. One striking feature of the current case is the very rapid repigmentation on the scar. We concluded that repigmentation on the scar at the time of suture removal, should raise suspicion for melanoma even if the pathology is benign. We should bear in mind that although the early repigmentation may remain in the scar, by time it may exceed the borders of the scar which is a more prominent feature for recurrent melanoma.

\section{Table 1. Distinctive features of different diagnostic} tools to differentiate recurrent nevus from melanoma

\begin{tabular}{|c|c|c|}
\hline & Recurrent nevus & Melanoma \\
\hline \multirow{4}{*}{ Pathologic features ${ }^{2,3,5,6}$} & $\begin{array}{l}\text { Monomorphous } \\
\text { cytology of } \\
\text { melanocytes and } \\
\text { small nuclei }\end{array}$ & $\begin{array}{l}\text { Cellular atypia and } \\
\text { prominent nuclei }\end{array}$ \\
\hline & $\begin{array}{l}\text { No mitoses, no } \\
\text { necrosis }\end{array}$ & $\begin{array}{l}\text { Presence of mitoses } \\
\text { and necrosis }\end{array}$ \\
\hline & $\begin{array}{l}\text { Presence of } \\
\text { melanocyte } \\
\text { nests at the } \\
\text { dermoepidermal } \\
\text { junction or in the } \\
\text { dermis }\end{array}$ & $\begin{array}{l}\text { Presence of } \\
\text { melanocytes at } \\
\text { various levels in the } \\
\text { epidermis/dermis }\end{array}$ \\
\hline & $\begin{array}{l}\text { Recurrent } \\
\text { pigmentation } \\
\text { restricted to the } \\
\text { scar }\end{array}$ & $\begin{array}{l}\text { Extention } \\
\text { of recurrent } \\
\text { pigmentation } \\
\text { beyond the scar }\end{array}$ \\
\hline \multirow{2}{*}{$\begin{array}{l}\text { Immunohistochemical } \\
\text { staining }^{5}\end{array}$} & $\begin{array}{l}\text { Gradual decrease } \\
\text { in } \mathrm{HMB}-45 \text { and } \\
\text { tyrosinase staining }\end{array}$ & $\begin{array}{l}\text { No gradual } \\
\text { decrease in HMB- } \\
45 \text { and tyrosinase } \\
\text { staining }\end{array}$ \\
\hline & $\begin{array}{l}\text { Lower percentage } \\
\text { of Ki-67 } \\
\text { proliferation index }\end{array}$ & $\begin{array}{l}\text { Higher percentage } \\
\text { of Ki-67 } \\
\text { proliferation index }\end{array}$ \\
\hline Dermoscopic features $^{9}$ & $\begin{array}{l}\text { Radial lines, } \\
\text { symmetry and } \\
\text { centrifugal growth } \\
\text { pattern }\end{array}$ & $\begin{array}{l}\text { Circles, peripheral } \\
\text { eccentric } \\
\text { hyperpigmentation, } \\
\text { non-continuous } \\
\text { growth pattern } \\
\text { and pigmentation } \\
\text { beyond the scar }\end{array}$ \\
\hline \multirow[t]{2}{*}{ Confocal microscopy ${ }^{8}$} & $\begin{array}{l}\text { Non-prominent } \\
\text { pagetoid or } \\
\text { lateral spread of } \\
\text { melanocytes }\end{array}$ & $\begin{array}{l}\text { Pleomorphic } \\
\text { dendritic pagetoid } \\
\text { cells with } \\
\text { folliculotropism }\end{array}$ \\
\hline & $\begin{array}{l}\text { Repigmentation } \\
\text { limited to the scar }\end{array}$ & $\begin{array}{l}\text { Repigmentation } \\
\text { extended into the } \\
\text { normal tissue }\end{array}$ \\
\hline
\end{tabular}




\section{Ethics}

Informed Consent: Informed consent was obtained from our patient. Peer-review: Internally peer-reviewed.

\section{Authorship Contributions}

Surgical and Medical Practices: G.E., S.K.Y., Ö.G., Ö.B., Concept: G.E., S.K.Y., Ö.G., S.D.G., Ö.B., H.K., Design: G.E., S.K.Y., Ö.G., S.D.G., H.K., Data Collection or Processing: G.E., S.K.Y., Ö.G., S.D.G., Ö.B., H.K., Analysis or Interpretation: G.E., S.K.Y., Ö.G., S.D., Ö.B., H.K., Literature Search: G.E., S.K.Y., Writing: G.E., S.K.Y., Ö.G., S.D.G., Ö.B., H.K.

Conflict of Interest: No conflict of interest was declared by the authors.

Financial Disclosure: The authors declared that this study has received no financial support.

\section{References}

1. Fox JC, Reed JA, Shea CR: The recurrent nevus phenomenon: A history of challenge, controversy, and discovery. Arch Pathol Lab Med 2011;135:842-6.

2. Kelly JW, Shen S, Pan Y, Dowling J, McLean CA: Postexcisional melanocytic regrowth extending beyond the initial scar: A novel clinical sign of melanoma. Br J Dermatol 2014;170:961-4.

3. Botella-Estrada R, Nagore E, Sopena J et al: Clinical, dermoscopy and histological correlation study of melanotic pigmentations in excision scars of melanocytic tumours. Br J Dermatol 2006;154:478-84.

4. Kornberg R, Ackerman AB: Pseudomelanoma: Recurrent melanocytic nevus following partial surgical removal. Arch Dermatol 1975;111:1588-90.

5. Hoang MP, Prieto VG, Burchette JL, Shea CR: Recurrent melanocytic nevus: A histologic and immunohistochemical evaluation. J Cutan Pathol 2001;28:400-6.

6. King R, Hayzen BA, Page RN, Googe PB, Zeagler D, Mihm MC Jr: Recurrent nevus phenomenon: A clinicopathologic study of 357 cases and histologic comparison with melanoma with regression. Mod Pathol 2009;22:611-7.

7. Urso C, Rongioletti $F$, Innocenzi $D$ et al: Histological features used in the diagnosis of melanoma are frequently found in benign melanocytic naevi. J Clin Pathol 2005;58:409-12.

8. Longo C, Moscarella E, Pepe P et al: Confocal microscopy of recurrent naevi and recurrent melanomas: a retrospective morphological study. $\mathrm{Br} J$ Dermatol 2011;165:61-8.

9. Blum A, Hofmann-Wellenhof R, Marghoob AA et al: Recurrent melanocytic nevi and melanomas in dermoscopy: results of a multicenter study of the International Dermoscopy Society. JAMA Dermatol 2014;150:138-45.

10. Song J, Mooi WJ, Petronic-Rosic V, Shea CR, Stricker T, Krausz T: Nevus versus melanoma: to FISH, or not to FISH. Adv Anat Pathol 2011;18:229-34. 